\title{
Articulating, reclaiming and celebrating the professionalism of teacher educators in England
}

Eline Vanassche*, Warren Kidd, Jean Murray

${ }^{*}$ Corresponding author

Dr. Eline Vanassche ${ }^{1}$, Marie Skłodowska-Curie fellow, University of East London,

Water Lane, Stratford Campus, London E15 4LZ, +442082234738,

e.vanassche@uel.ac.uk.

Dr. Warren Kidd, University of East London, Water Lane, Stratford Campus, London E15 4LZ, +442082236475, w.kidd@uel.ac.uk.

Professor Jean Murray, University of East London, Water Lane, Stratford Campus, London E15 4LZ, +442082236318, j.m.f.murray@uel.ac.uk.

Funding

This project has received funding from the European Union's Horizon 2020 research and innovation programme under the Marie Sklodowska-Curie grant agreement No 751294.

\footnotetext{
${ }^{1}$ On 1st December 2018, Dr. Eline Vanassche was appointed as an Assistant Professor at the University of Leuven, Belgium. New contact address: Faculty of Psychology and Educational Sciences, Campus Kulak Kortrijk / KU Leuven, Etienne Sabbelaan 51 (P.O. 7654), 8500 Kortrijk, Belgium, eline.vanassche@kuleuven.be.
} 


\section{Articulating, reclaiming and celebrating the professionalism of teacher educators in England}

\section{Abstract}

This paper examines the cumulative effects on teacher educators of a series of ideological and policy changes in the English teacher education landscape since the early $80 \mathrm{~s}$. We argue that these rapid changes have marginalized the role of the university in teacher learning and resulted in narrower, more instrumental forms of teacher education. Within this landscape we see a distinct need to re-state (and reinstate) the importance of higher education-based teacher educators, and to reclaim and celebrate their practices and the nature of the professionalism involved. We invite the reader to rethink teacher educator professionalism as what is enacted by teacher educators, as engaged in their professional activities. A view of enacted professionalism gives central stage to and trusts the professional judgement of teacher educators to do what they deem is good, appropriate, or best - understood in a broad sense - to support the professional learning of newcomers in the profession.

Keywords: Professionalism; Enacted; Practice

\section{Introduction}

Although teacher educators were once an under-researched, poorly understood and ill-defined occupational group (Loughran and Russell 1997; Murray 2002), the amount of research on them has grown steadily and they have become more 
prominent in policy agendas in the last decade (see EC 2013). The European Commission (2013) refers to teacher educators as a 'profession increasingly in the public eye' (6), yet, at the same time, there is concern over the increasing 'tensions arising from the fragmentation of the profession over a variety of institutional contexts' (12). This is not least because of the recognition of their centrality in the pedagogies and practices of pre-service or Initial Teacher Education (ITE). The workplace landscape for this occupational group demonstrates an increasing complex diversity. In the UK these complex changes for teacher educators are part of the wider increasing 'uncertain times' of teacher education and teacher educators' practice across Europe (George and Maguire, 2018). Within this range of national contexts, there is evidence of the 'accelerated' pace for change and paradoxes, challenges and tensions between on the one hand a drive for standards and on the other 'the advocacy of a need for an expanded professionalism' (MadalińskaMichalak, O’Doherty, and Assunção Flores 2018, 567). To explore the significance of teacher educators' professionalism, we note that in moving on from an initial period of teacher learning, teacher educators are often present throughout the whole teacher life cycle, not just inducting newcomers into the profession, but also modelling, exemplifying and updating professional practice, and undertaking research that informs learning and teaching in the field. It is often argued then that, just as the quality of learning in schools is dependent in considerable part on the quality of teachers, so the quality of teacher education is dependent on teacher educators (EC 2013).

In this paper we focus on teacher educators because of this centrality. Internationally, teacher educators are acknowledged to be a heterogeneous 
occupational group (Davey 2013; Izidinia 2014), working from Higher Education Institutions (HEI) and schools, in many and varied roles to support teachers. There has long been a 'problem of definition' (Ducharme 1993, 2) in discussing this occupational group, in part because of these diverse roles and work patterns within the field, but also because of issues around self- and communal-ownership of the term. A further factor is that teacher educators' professionalism, knowledge bases and pedagogies are complex and difficult to define: they are characterised by the uncertain, ill-defined and under-valued nature of the professional knowledge and skills needed to teach teachers. This view has been prevalent in the English discourse around teaching as a 'craft' from successive neo-liberal educational reforms over the past 15 years (Gove 2010a). Commentators have noted that these changing professional discourses have a convergence around neo-liberal conceptions of educating teachers as a matter of a 'training' paradigm (Beach and Bagley 2013).

Our first focus in this paper explores the nature of such reforms designed to open up the ITE 'market' to new, employment-based routes into teaching. The implications of the changing teacher education landscape for the roles, identities and practices of teacher educators are discussed in the second section. These policies present a 'turn to the practical' (Furlong and Lawn 2011) which marginalizes the role of the university in teacher learning. We argue that, the cumulative effects of these ideological and policy changes in the English landscape have de-professionalised teacher educators and affected their work and status, often causing them to be (wrongly) positioned as only 'semi-academics' (Ducharme 1993; Murray 2002) or as 'out of touch' with schools (Brown et al. 2015; Gove 2010a); both these positions 
cause their professionalism to be overlooked, devalued or dismissed by policymakers. Then, we examine how the current ideological and political teacher education landscape not only de-professionalizes teacher educators, but also appeals to the more instrumental or 'performative' (Beck 2009) dimensions of teaching. Within this landscape we see a distinct need to re-state (and reinstate) the importance of teacher educators, and to reclaim and celebrate their practices and the nature of the professionalism involved. In response to this call, we then put forward a model of enacted professionalism that gives way to teacher educators' professional judgment to do what they deem is good, appropriate, or best understood in a broad sense - to support the professional learning of newcomers in the profession. The paper concludes with a proposal for more productive professional learning and development initiatives for teacher educators inferred from this alternative view of professionalism.

\section{The changing English landscape}

ITE in England has been subjected to repeated interventions by central government and its agencies since 1984, as part of an ever-present focus on raising educational standards in schools. The pace of 'reform' increased radically from 2010 onwards as the incoming Coalition government made wide-ranging changes to ITE provision, influenced by a model of teaching and the teaching profession as a basic 'craft' involving limited knowledge beyond a subject-specialist degree (Gove 2010a) and best learned through apprenticeship in schools. The changes were also underpinned by scepticism, whether explicit or implicit, about the value of the universities' contributions to ITE. At the centre of reform were the introduction and intensification of interventions leading to new school-led models of training, designed to open up 
the 'market' of ITE to new 'providers' (a term that indicates organisations validated to educate teachers). There are now many such 'providers' and a number of diverse and alternative routes into teaching. The main instrument of the ITE reforms since 2010 has been the employment-based route called School Direct (for further details, see Brown, Rowley, and Smith 2015; Murray, Czerniawski, and Kidd 2017) in which schools recruit graduates who wish to become teachers, provide the majority of their school experience and arrange other professional learning opportunities. First introduced as a small-scale pilot in 2011, the School Direct scheme is now a very significant route into the profession, with its impact compounded by a revised and more rigorous inspection framework aimed at improving the performance of the sector. These changes have, in some contexts, resulted in narrower and more instrumental forms of ITE, constructed around strong 'local' knowledge, ignoring broader constructions of teacher education and teaching as necessarily researchinformed (Murray et al. 2017).

ITE in England now exists within a fast changing, fragmented and diversifying teacher education system in which there are multiple 'providers' of programmes and diverse routes into teaching existing alongside - and sometimes inter-woven with traditional study at degree or post-graduate levels. Some commentators present diversification as a 'struggle for teacher education' (Trippestad, Swennen, and Werler 2017) while others point to the struggle for 'disruptive narratives' within professional spaces scrutinized by changing policy (Kennedy 2018). Clarke and Phelan (2015) refer to the intensification of policy change (in this case around teacher education) as a 'policy hyperactivism' where rapid development and deployment of policy is used to create public illusion of governance with authority 
and order. The rate of much reform is rapid leading to a highly diverse and fragmented system, both of schools and schooling and routes for teacher learning. Whitty $(2014,471)$ sees this fragmented context as resulting from the 'neo-liberal combination of the strong state and the free market'.

In England, ITE has moved away from the exclusive dominance and domain of universities or $\mathrm{HEI}$ as seen in most of the twentieth century, and towards schools as far more influential stakeholders. The principle of Higher Education making distinctive and necessary contributions to ITE has been steadily eroded in the multiplicity of providers and routes now involved in the 'marketplace' of school-led ITE. Cumulatively, government interventions have changed the language, cultures, governance, regulatory structures and institutional organisation of ITE, making it a more school-focused and instrumental enterprise (Furlong 2013) and centring legitimation on 'practical' knowledge of teaching (Murray and Mutton 2015). This emphasis on alternative, school-based routes has significant implications for teacher educators as an occupational group and for their roles, identities and practices, as we now identify.

\section{Changing teacher educator positions}

Perhaps the most significant result of change has been the enlargement of the occupational group of teacher educators. Only a decade ago, in England as in many other countries, this group could be defined, in the main, as those employed by universities on full or part-time contracts (Murray 2005; Davey 2013). This HEl-based occupational group has now been joined by various types of school-based teacher educators, with the School Direct route, in particular, bringing a new cohort of such 
educators into ITE. For example, in addition to traditional mentoring roles, established in the early 1990s for supporting the practicum, there are now those with responsibility for organising all aspects of ITE, including recruitment, design and implementation of programmes, teaching and mentoring and assessment at the end of the training process, all within the school workplace. Depending on the type of training route offered in their schools, they sometimes - but not always - work alongside the traditional cohort of HEl-based teacher educators.

Studies of school-based teacher educators (see, inter alia, Czerniawski et al. 2017; White et al. 2015) give numerous examples of new practices being 'grown-on' or 'extended' from previous ways of working as mentors. This new occupational group show considerable confidence in the knowledge, experience and skills they now possess to be teacher educators, and to take on extended responsibilities for ITE in their schools, often operating in Zeichner's (2010) 'third spaces'. Zeichner's (2010) original description of the third space focused on the creation of 'hybrid spaces' that move beyond a view of academic knowledge 'as the authorative source of knowledge about teaching' (89) to 'a nonhierarchical interplay between academic, practitioner, and community expertise ... that will create expanded learning opportunities for prospective teachers' (89). Yet, we would argue that, the hybrid spaces created in the current ideological and political landscape inadvertently establish a new epistemological hierarchy in which knowledge that exists in practice chokes the academic knowledge and skills that exist among HEl-based teacher educators in an increasingly marketised field, thereby narrowing rather than expanding prospective teachers' learning opportunities, and strongly impacting the 
work, roles and identities of this more traditional group of HEl-based teacher educators.

Research on HEl-based teacher educators shows that their work has long been characterised by heavier workloads, longer teaching hours and less research engagement than typically undertaken by other academic groups (Maguire 1994; Murray 2002). McNamara et al. (2017) argue that, the fragmentation and increasing marketisation of the field since 2010 has meant that the position of these HEI-based teacher educators has worsened, not least because they have faced significant job losses, derogation of their traditional expertise, considerable changes in their institutional cultures, work patterns and attitudes to work, and changes to professional knowledge bases and identities (see Brown et al. 2015; Murray et al. 2017).

Brown et al.'s study (2015), for example, found that HEl-based teacher educators had experienced major changes in their professional roles and responsibilities. In particular, ways of understanding subject identities and subject knowledge, ways of participating in research and teacher education work, and perceptions of the importance of school experience had all shifted. Teacher educators were more likely to define their 'practice with reference to their own expertise in schools, rather than ... the more traditional academic capabilities mentioned in their job descriptions' (Brown et al., ibid, 2). This study also notes that, whilst experienced teacher educators were adjusting to changing work conditions and roles, they often felt 'displaced'. All were 'now less able to compete with school-based teacher educators in meeting the demands of immediate practice' (7). The compound effects of these 
factors on the field had been to shore up 'the new operationally orientated priorities in the discourse of the university' (505).

Murray et al.'s study (2017) identified that School Direct, in particular, had brought about significant changes including: teacher educators' engagement in 'selling' their courses to schools; the marginalisation of teacher educator experience in recruitment; revised forms of curriculum and assessment practices emerging to accommodate school requirements; and extended forms of guidance for developing ITE pedagogies offered to schools by HEI-based teacher educators. These teacher educators were commonly negotiating new structures and content in the programmes they were offering to schools. They were also taking on marketing work with schools, to 'win' contracts for training, engaging in widespread consultancy roles in the school sector, and systematically 'transferring' their knowledge of how ITE works to their school partners. This is in part a result of the 'boundary-crossing' nature of the profession (Williams 2013) in having come from schools in their 'firstorder' professional role. All of these policies represent a 'turn to the practical' (Furlong and Lawn 2011) which marginalize the role of the university in an increasingly marketised field.

Struggles around research engagement continued to be a powerful signifier of credibility and value in studies of teacher educators' work and identities (Brown et al. 2014; Murray 2014). University demands for research performativity are manifested in increasingly differentiated forms of research engagement by teacher educators. These demands often co-existed uneasily with the increasing emphasis on practice and the development of school-led ITE. Compounding this reshaping of professional 
identities were attacks on teacher educators coming from policy-makers, the media and stakeholders within other sectors of education, particularly in the years 20102013 (Department for Education 2010). These changes represent significant change in the ideological construction of practice, curriculum and quality assurance, and how practice and professionalism are defined, enacted and maintained.

Such debates around teaching as craft and the resulting changes to teacher education frameworks have implications for teacher professionalism, and in turn, teacher educator professionalism. Controversial Coalition policy rhetoric suggests that 'teaching is a craft and it is best learnt as an apprentice observing a master craftsman or woman' (Gove 2010a), and, 'you learn how to be a great teacher by observing already existing great teachers and, in turn, by being observed yourself' (Gove 2010b). Here we have teaching and the education of the profession as 'an apprenticeship'. Forms of ITE which involve Higher Education are implicitly positioned as lacking authority and legitimacy since they 'drew gifted young teachers away from their vocation and instead directed them towards ideologically driven theory' (Gove 2013). These interpretations of craft have implications for how teacher learning is seen, and for the legitimacy of the sources of teacher and teacher educator knowledge bases. As such they shape university and school responses to the ways in which pre-service and in-service learning opportunities are created. They lend legitimacy to practice-based professional learning practices over other routes (Orchard and Winch 2015; Brown et al. 2015).

Overall, as Brown et al. $(2015,7)$ argue, emerging new models of school-led ITE are 
impacting on ... how the categories "teacher educator", "teacher" and "trainee" are defined'. In particular, the function of "teacher educator" has been split across the university and school sites, displacing traditional notions of what it means to be a "teacher" and "teacher educator".

Whilst there are clear indications that the changes to the ITE system have brought new practices to many schools, for HEl-based educators they have brought shifting roles and types of work, forming new - and often more instrumental - practices and relationships amidst shifting forms of power relations, autonomy, trust and economic models in ITE. There are, of course, complex tensions around these new - and sometimes diverging - practices for all teacher educators, wherever they are located, in brokering and navigating change. In effect, all these teacher educators are creating new spaces, structures and relationships in action as the landscape of teacher education shifts around them. But we argue that, overall, these changes, alongside shifts in the epistemologies and locations for the majority of ITE, have brought profound, long-term and adverse alterations to the ways in which HEI-based teacher educators define and enact their professionalism. In the next section, we build on this claim and explore in more detail how the contested, yet nonetheless influential policy rhetoric has (re)framed 'good' teaching and teacher education.

\section{Teacher education redefined}

The view held by critics of neo-liberal reform suggests that if seen as a craft, teaching is reduced in its professional standing, as are the second-order professionals (Murray 2002) - the teacher educators - who 'educate' or 'train' this 'profession'. For example, Winch (2011) re-applies the notion of a 'restricted 
professional' (Hoyle 1974) and comments that the teacher-as-craft worker has 'no interest in theoretical knowledge and whose practice is based on experience and intuition, rather like that of a traditional craft worker' (18). In this view, being a craft is de-professionalising since 'craft work does not involve the application of theory to practice' (17). Wisdom of practice (Shulman 2004) is emphasized at the dispense of wisdom of theory, the latter referring to theoretical models and concepts that operate as a lens to analyse and make sense of the particular situation in which one finds oneself and decide how to act in it. According to this line of logic, the expertise of teaching is assumed to exist largely in schools, with teachers, and is also developed there. If one conceives of teaching as a set of technical skills 'that can be picked up in practice' (Biesta 2012, 9), then teacher education is best conceived of as a practical experience in schools. The best guarantee for high-quality teaching is having novices observe, import and perform '(what) the most able exemplars of accomplished practice ... do, and do well' (Shulman et al. 2006, 29).

The current ideological and political teacher education landscape not only repositions theory and practice, but also appeals to the more instrumental or 'performative' (Beck 2009) dimensions of teaching. Underpinning the 'turn to the practical' and related push toward school-led ITE is a focus on 'what works'. In such a view, being and becoming a 'professional' teacher 'is a matter of acquiring a limited corpus of state prescribed knowledge accompanied by a set of similarly prescribed skills and competencies. This model is a technicist one involving the acquisition of trainable expertise' (Beck 2009, 8; see Brown et al. 2015). This technicist model is further supported by the Teacher Standards for England that predominantly focus on what teachers do, or should be able to, rather than what and how they think about 
practice (Evans 2011), and the accountability measures for teachers and schools in England that take pupil progress as an increasingly important measure of success in education (Acquah 2013).

One risk of such a focus on 'what works' or the means of education, is forgetting about what Zeichner (1983) labelled 'the prior and more fundamental questions related to purposes and ends' (emphasis in original, 3). Questions of purposes and ends have become difficult in the neoliberal discourse on accounting and transparency. "The focus on "what works" makes it difficult if not impossible to ask the questions of what it should work for and who should have a say in determining the latter' (Biesta 2007, 5). The debate about what is good teaching and what kind of teachers one aims to educate is prematurely closed or considered irrelevant or redundant, because the answers to these questions have presumably already been given, for example, in the teacher standards or in using existing practice in schools as a template for future practice. This more technicist model of teaching has eroded the role of teacher educators to that of 'experienced practitioners' who equip trainees with the 'right' instrumental-technical knowhow to teach.

In this case, with experiential knowledge central to a legitimation claim of professionalism, alternative basis for authority are often undervalued. This positioning of professionals who were 'once a teacher' (Murray 2014; Murray et al. 2017) - or still are teachers - leads some commentators to see the profession as a 'boundary-crossing' profession (Murray and Male 2005; Swennen and Van Der Klink 2009; Williams 2013). Yet, in a different way, the (re)deployment of the term craft in neo-liberal discourse in England also repositions teacher educators as practitioners 
and redefines the substance and texture of their professionalism due to its nature as a second-order practice. Alternative versions of craft are often overlooked in this policy context (see GTC Scotland 2014; Kidd 2013).

\section{Reclaiming teacher educator professionalism}

We argue that the cumulative effects of these ideological and policy changes have de-professionalized the work of educating teachers and swept away teacher educators' autonomy and control over their professional roles and responsibilities. This argument does not serve to demean the authority of experience (Munby and Russell 1994), nor the importance of technical skills for teaching. Yet, practical knowledge and experience have become 'god terms' (Burke 1952) compared to which all other aspects of teaching and teacher education are ranked as subordinate. In using current teaching practice as a template for the education of newcomers to the profession, however able or accomplished these exemplars of practice are, we accept and recreate rather than transform and renew current schooling. But beyond that, we also accept that the boundaries within which teacher educators can or may exercise professional judgment and take responsibility themselves are set by current school practice.

Underlying the current ideological and political landscape, we would therefore argue, is a conception of demanded or even prescribed professionalism (Evans 2008). Existing school practice is an articulated perception of what lies within the parameters of acceptable professional behaviour, roles and attitudes of teachers and therefore teacher educators. It presents the blueprint (Kelchtermans 2013) for the knowledge, skills, and attitudes that teacher educators need to master or actively 
strive towards in order to legitimately consider themselves as 'professional' teacher educators (see Kelchtermans 2013; Vanassche and Kelchtermans 2014). Who is designated as a 'professional' teacher educator is someone who has tested his/her knowledge in the 'real world' of practice, knows 'what works', and is effective in imparting this technical knowhow on trainees, in much the same way as for teachers. Korthagen, Loughran and Russell (2006) rightly reminded us of the risk here of creating the very reverse problem of the reality shock faced by beginning teachers: 'teacher education seemed to boil down to learning the tricks of the trade, without much deepening through theory' (1021).

If it is time to reclaim professionalism, then the (shifting) spaces that teacher education operates within become even more significant. While operating in 'hybrid places' (Zeichner 2010) between schools and universities teacher educators have previously been re-framed as 'consultants' or as post-modern 'brokers' given the increasing importance of partnership in reformed school-based models (Lunenberg, Dengerink, and Korthagen 2014). But the profession needs to be more than this. Moving away from brokerage, teacher educators need to reclaim a professionalism distinct from being 'in between'. As Swennen and van der Kink (2009) suggest, the profession of teacher educators 'need to act in such ways that other stakeholders, including policy makers and education authorities, recognise' their authority, experience and legitimacy.

In an effort to articulate, reclaim and celebrate the professionalism of teacher educators in England, we invite the reader to rethink teacher educator professionalism not as what is prescribed by the contours of the current political or 
practice landscape, but as what is enacted by teacher educators, as engaged in their professional activities. The term 'enacted' emphasizes what is actually happening in practice, as opposed to normative definitions of what should happen in that practice, for example, in terms of imparting 'best' practices (Kelchtermans 2013; Vanassche and Kelchtermans 2014). The starting point of an enacted approach to professionalism is thus fundamentally different from the one underpinning the current ideological and political landscape in England. A view of enacted professionalism gives central stage to and trusts the professional judgement of teacher educators to do what they deem is good, appropriate, or best - understood in a broad sense - to support the professional learning of newcomers in the profession. Rather than prescribing or replacing their professional judgment by a universal set of 'best' practices, we accept that teacher educators have good reasons to do what they do in practice, and that this important role needs to be met with adequate professional development support. From a view of enacted professionalism, professionalism is inherently neutral as "something that is rather than something that ought to be" (Evans 2011, 855, emphasis in original; see Evans 2008). It does not just apply to a special category of teacher educators, such as experienced first-order practitioners. Following Evans (2011), professionalism is a mere descriptor of teacher educators' observed professional practices, actions and judgments, and the rationale underpinning these. Professionalism, from an enacted view, is about how teacher educators go about their practice and why (incorporating aspects of one's professional biography as an academic, subject specialist, former teacher, but also aspects of one's broader professional context); the goals one strives for; one's beliefs about interventions that might support the accomplishment of these goals; the knowledge built into one's actions; and the level of consistently in all these aspects. 
Conceiving of professionalism as being enacted in and through practice, implies acceptance of the fact that it is not a stable entity (that again could be mapped and prescribed). Rather, it is continuously (re)shaped in response to the needs of a particular practice situation, and others - trainees and the children in their future classrooms, but also colleagues, school-based mentors, etc. - in that situation. Professionalism is a dynamic construct that is constantly being defined and redefined through the actions that individual teacher educators and communities of teacher educators take, and the individual and collective sense-making, relationships, experience, theory, organizational settings, policy frameworks, etc. that informs it.

A view of enacted professionalism re-shifts power and gives way to teacher educators' autonomy, but should not be read as a plea for freeing the profession from any sense of accountability. Quite the contrary: teacher educators keep the ownership of, and thus also the responsibility for, the teaching and learning processes. In enacting practice in a specific way, one takes a stance as a teacher educator; one communicates a particular view (argument) of good teaching and dismisses others, for very good reasons, and one thus exercises a choice (albeit not often felt consciously) (Kelchtermans 2009). If we consider practice as sending professional messages, then the ways teacher educators enact practice entails a particular response or position towards the ideological, political, organizational setting and demands, or changes in the educational environment. Taking such a view thus has enormous emancipatory and professional development potential for 
teacher educators and positions teacher educators as the agents, rather than the objects of reform (Cochran-Smith, Keefe, and Carney 2018).

In re-defining the professionalism of teacher educators, Gramsci's (1971) notion of 'good sense', as opposed to 'common sense', is useful as it allows us to reclaim the authority from experience and research that are central to (reclaimed) notions of teacher educator professionalism. In adopting the Gramscian notion of 'good sense', Orchard and Winch (2015) argue, 'the professional teacher is able to judge right action in various school and classroom contexts from a more reliable basis for judgment than intuition or common sense' (14). The important point made here is that being a 'professional' teacher is not only a matter of acquiring and performing the technical means (knowhow) to teach towards predefined purposes and ends. Rather, it is about judging when and how to apply one's technical skills for what is good - and good needs to be understood broadly, not just in terms of qualification for a particular group of children, here and now (Biesta 2012). The teacher education experience should support trainees in carefully and critically examining what and why they do what they do, its effects - understood broadly - and whether or not that aligns with their purposes. It is important to see this as not just a dimension 'missing' in the current teacher education landscape, but as something that undermines the ontological and epistemological validity of the current approach to teacher education as a whole.

\section{Conclusion}

Through an analysis of the shifting landscape of ITE in England, followed by an exploration of its impact on the roles, identities, and practices of teacher educators 
and operating views of teaching and teacher education, This paper has argued that an enacted view of teacher educator professionalism may well have potential to articulate, reclaim and celebrate anew the practice of teacher educators in England and beyond. Looking at what teacher educators do and reclaiming their authoritative professional judgments is essential for teacher educator authority in the light of diversity and fragmentation of the current landscape.

A view of enacted professionalism is more than an alternative conceptual lens to think and talk about teacher educator professionalism, but also offers a concrete perspective to actively work on and develop such professionalism. It questions the dominant approach to the professional development of teacher educators taken in many European countries recently: the development of a set of teacher educator standards that map - and prescribe - 'the functions and tasks teacher educators should have' and 'the knowledge and skills they should have' (Koster and Dengerink $2001,345)$. According to a view of enacted professionalism, it has little empirical and conceptual value to think about the professionalism of teacher educators as an individual possession (a state to be achieved) or a general, context-free descriptor of the quality of the work and knowledge involved. Until enacted, professionalism is nothing but an aspiration (Evans 2011). It only becomes real (i.e. visible) in practices enacted by teacher educators, in a specific time and place. From a view of enacted professionalism, there is thus first and foremost a need for a close, interpretative analysis of the complex, relational, contextualized practices that make up teacher education and the nature of the professionalism involved. For this, we need to acknowledge and positively value the complexity and messiness of the work of teaching and teaching about teaching: we need to seriously consider the 
investigation of that complexity as professionally challenging and rewarding (Loughran 2006). The Self-Study of Teacher Education Practices (S-STEP) community (Loughran et al. 2004) has offered examples of what such an approach could look like.

Putting central and trusting the professional practices and judgment of teacher educators, rather than specifying clear standards of performance (i.e., professional standards for all teacher educators regardless of their working sector), has many, admittedly, difficult consequences. It could easily be misread as 'letting a thousand flowers bloom'; something which the profession has been accused of before (see Falk 2006, 76) given its lack of systematized induction routes or professional development support. Again, this is not a plea to free teacher educators from any sense of accountability for what they do, but teacher educators should not be primarily held accountable towards an external, assessing body, but towards their collegial working environment, including the collegial environment provided by schools and, beyond that, the research community in the broad field of teaching and teacher education. Here is an important role to play for school-university partnerships and having thorough conversations about the quality of the teaching and learning experience: such conversations imply the possibility to adjust, correct, or refine a professional judgment.

\section{References}

Acquah, Daniel. 2013. School Accountability in England: Past, Present and Future. Manchester: Centre for Education Research and Policy. 
Beach, Dennis, and Carl Bagley. 2013. "Changing Professional Discourses in Teacher Education Policy back towards a Training Paradigm: A Comparative Study." European Journal of Teacher Education 36 (4): 379-392.

doi:10.1080/02619768.2013.815162

Beck, John. 2009. "Appropriating Professionalism: Restructuring the Official Knowledge Base of England's 'Modernised' Teaching Profession." British Journal of Sociology of Education 30 (1): 3-14. doi:10.1080/01425690802514268

Biesta, Gert. 2007. 'Why 'What Works' Won’t Work: Evidence-based Practice and the Democratic Deficit in Educational Research." Educational Theory 57 (1): 1-22. doi:10.1111/j.1741-5446.2006.00241.x

Biesta, Gert. 2012. "The Future of Teacher Education: Evidence, Competence or Wisdom?" Research on Steiner Education 3 (1): 8-21.

Brown, Tony, Harriet Rowley, and Kim Smith. 2014. "Rethinking Research in Teacher Education." British Journal of Educational Studies 62 (3): 281-296. doi:10.1080/00071005.2014.955080

Brown, Tony, Harriet Rowley, and Kim Smith. 2015. The Beginnings of School Led Teacher Training: New Challenges for University Teacher Education. School Direct Research Project Final Report. Manchester: Manchester Metropolitan University. Bullock, S. M. 2012. "Creating a Space for the Development of Professional Knowledge: A Self-study of Supervising Teacher Candidates during Practicum Placements." Studying Teacher Education 8 (2):143-156.

doi:10.1080/17425964.2012.692985

Burke, Kenneth. 1952. A Grammar of Motives. New York: Prentice Hall. 
Clarke, Matthew, and Anne Phelan. 2015. "The Power of Negative Thinking in and for Teacher Education." Power and Education 7 (3): 257-271. doi:10.1177/1757743815607025.

Cochran-Smith, Marilyn, Elizabeth Stringer Keefe, and Molly Cummings Carney. 2018. "Teacher Educators as Reformers: Competing Agendas." European Journal of Teacher Education 41 (5): 572-590. doi: 10.1080/02619768.2018.1523391 Czerniawski, Gerry, Warren Kidd, and Jean Murray. 2019. "We Are All Teacher Educators Now: Understanding School-based Teacher Educators in Times of Change in England." In International Research, Policy and Practice in Teacher Education: Insider Perspectives, edited by Jean Murray, Anja Swennen, and Clare Kosnik, 171-185. London: Springer.

Davey, Ronnie. 2013. The Professional Identity of Teacher Educators: Career on the Cusp? London: Routledge.

Department for Education. 2010. The Importance of Teaching: The Schools White Paper 2010. London: HMSO.

Ducharme, Edward. 1993. The Lives of Teacher Educators. New York: Teachers College Press.

European Commission. 2013. Supporting Teacher Educators for Better Learning Outcomes. European Commission.

Evans, Linda. 2008. "Professionalism, Professionality and the Development of Education Professionals." British Journal of Educational Studies 56 (1):20-38. doi:10.1111/j.1467-8527.2007.00392.x

Evans, Linda. 2011. “The 'Shape' of Teacher Professionalism in England:

Professional Standards, Performance Management, Professional Development and 
the Changes Proposed in the 2010 White Paper." British Educational Research Journal 37 (5): 851-870. doi:10.1080/01411926.2011.607231

Falk, Beverly. 2006. "A Conversation with Lee Shulman - Signature Pedagogies for Teacher Education: Defining our Practices and Rethinking our Preparation." The New Educator 2: 73-82. doi:10.1080/15476880500486145

Furlong, John. 2013. Education - An Anatomy of the Discipline. London: Routledge. Furlong, John, and Martin Lawn, eds. 2011. Disciplines of Education: Their Role in the Future of Education Research. London: Routledge.

George, Rosalyn, and Meg Maguire. 2018 (e-pub ahead of print). "Choice and Diversity in English Initial Teacher Education (ITE): Trainees' Perspectives." European Journal of Teacher Education. doi:10.1080/02619768.2018.1544613 Gove, Michael. 2010a. Speech to the National College for School Leadership. June 16. http://www.education.gov.uk/inthenews/speeches/a0061371/michael-gove-to-thenational-college-annual-conference-birmingham.

Gove, Michael. 2010b. The Responsibilities of the Secretary of State - Education Committee: Examination of Witnesses.

http://www.publications.parliament.uk/pa/cm201011/cmselect/cmeduc/395-i/395i05.htm.

Gove, Michael. 2013. "I Refuse to Surrender to the Marxist Teachers Hell-bent on Destroying our Schools: Education Secretary Berates 'the Bew Enemies of Promise' for Opposing his Plans." Daily Mail, March 23.

Gramsci, Antonio. 1971. Selections from the Prison Notebooks of Antonio Gramsci. London: Lawrence and Wishart.

General Teaching Council for Scotland. 2014. Teachers' Professional Knowledge: A View from Scotland. http://www.philosophy-of- 
education.org/uploads/2014\%20Conference/Papers/Hamilton_Hogan_Oancea.pdf Hoyle, Eric 1974. "Professionality, Professionalism and Control in Teaching." London Education Review 3 (2): 15-17.

Izadinia, Mahsa. 2014. "Teacher Educators' Identity: A Review of the Literature." European Journal of Teacher Education 37 (4): 426-441. doi:

10.1080/02619768.2014.947025.

Kelchtermans, Geert. 2009. "Who I am in how I teach is the message. Selfunderstanding, vulnerability and reflection." Teachers and Teaching 15 (2): 257-272. doi:10.1080/13540600902875332

Kelchtermans, Geert. 2013. "Praktijk in de Plaats van Blauwdruk. Over het Opleiden van Lerarenopleiders." [Practice Instead of Blueprint. Educating Teacher Educators.] Tijdschrift voor Lerarenopleiders 34: 89-99.

Kennedy, Aileen. 2018. "Developing a New ITE Programme: A Story of Compliant and Disruptive Narratives across Different Cultural Spaces." European Journal of Teacher Education 41 (5): 638-653. doi:10.1080/02619768.2018.1529753 Kidd, Warren. 2013. “Framing Pre-service Teachers' Professional Learning Using Web2.0 Tools: Positioning Pre-service Teachers as Agents of Cultural and Technological Change." Professional Development in Education 39 (2): 260-272. doi:10.1080/19415257.2012.762419

Korthagen, Fred, John Loughran, and Tom Russell. 2006. “Developing Fundamental Principles for Teacher Education Programs and Practices." Teaching and Teacher Education 22 (8): 1020-1041. doi:10.1016/j.tate.2006.04.022 Koster, Bob, and Jurriën Dengerink. 2001. "Towards a Professional Standard for Dutch Teacher Educators." European Journal of Teacher Education 24 (3): 343-354. doi:10.1080/02619760220128897 
Loughran, John. 2006. Developing a Pedagogy of Teacher Education. London: Routledge.

Loughran, John, and Tom Russell. 1997. Teaching about Teaching: Purpose, Passion and Pedagogy in Teacher Education. London: Falmer Press.

Loughran, J. J., M. L. Hamilton, V. K. LaBoskey, and T. L. Russell, eds. 2004. International Handbook of Self-study of Teaching and Teacher Education Practices. Dordrecht: Kluwer Academic Publishers.

Lunenberg, Mieke, Jurriën Dengerink, and Fred Korthagen. 2014. The Professional Teacher Educator Roles, Behaviour, and Professional Development of Teacher Educators. Rotterdam: Sense Publishers.

Madalińska-Michalak, Joanna, Teresa O’Doherty, and Maria Assunção Flores. 2018. "Teachers and Teacher Education in Uncertain Times." European Journal of Teacher Education 41 (5): 567-571. doi:10.1080/02619768.2018.1532024

Maguire, Meg. 1994. The Job of Educating Teachers. Unpublished PhD thesis, Kings College, University of London, London.

McNamara, Olwen, Murray Jean, and Rebecca Phillips. 2017. Policy and Research Evidence in the 'Reform' of Primary Initial Teacher Education in England. Cambridge: Cambridge Primary Review Trust.

Munby, Hugh, and Tom Russell. 1994. "The Authority of Experience in Learning to Teach." Journal of Teacher Education 45 (2): 86-95.

doi:10.1177\%2F0022487194045002002

Murray, Jean. 2002. "Between the Chalkface and the Ivory Towers? A Study of the Professionalism of Teacher Educators Working on Primary Initial Teacher Education Courses in the English Education System." PhD diss., University of London. 
Murray, Jean. 2005. Re-addressing the Priorities: New Teacher Educators'

Experiences of Induction into Higher Education. European Journal of Teacher

Education 28 (1): 32-46. doi:0.1080/02619760500040108

Murray, Jean. 2014. “Teacher Educators' Constructions of Professionalism: A Case

Study." Asia-Pacific Journal of Teacher Education 42 (1):7-21.

doi:10.1080/1359866X.2013.870971

Murray, Jean, Gerry Czerniawski, and Kidd Warren. 2017. "The Impact of Alternative Routes on the Work and Identities of Teacher Educators: The English Case." In Getting the Teachers We Need: International Perspectives on Teacher Education, edited by Sharon Feiman-Nemser and Miriam Ben-Peretz, 11-22. London: Rowman and Littlefield.

Murray, Jean, and Trevor Male. 2005. "Becoming a Teacher Educator: Evidence from the Field." Teaching and Teacher Education 21 (2): 125-142.

doi:10.1016/j.tate.2004.12.006

Murray, Jean, and Trevor Mutton. 2016. "Teacher Education in England: Change in Abundance, Continuities in Question." In Teacher Education in Times of Change, edited by The Teacher Education Group, 57-74. Bristol: Policy Press.

Orchard, Janet, and Christopher Winch. 2015. "What Training Do Teachers Need? Why Theory is Necessary to Good Teaching." Impact 22: 1-43. doi:10.1111/2048416X.2015.12002.x

Shulman, Lee. 2004. The Wisdom of Practice: Essays on Teaching, Learning, and Learning to Teach. San Francisco: Jossey-Bass.

Shulman, L. S., C. M. Gold., A. C. Bueschel, and K. J. Garabedian. 2006. “Reclaiming Education's Doctorates: A Critique and a Proposal." Educational Researcher 35 (3): 25-32. doi:10.3102\%2F0013189X035003025 
Swennen, Anja, and Marcel van der Klink, eds. 2009. Becoming a Teacher Educator: Theory and Practice for Teacher Educators. Heidelberg: Springer.

Trippestad, T. A., A. Swennen, and T. Werler, eds. 2017. The Struggle for Teacher Education: International Perspectives on Governance and Reforms. London: Bloomsbury.

Vanassche, Eline, and Geert Kelchtermans. 2014. "Teacher Educators' Professionalism in Practice: Positioning Theory and Personal Interpretative Framework." Teaching and Teacher Education 44: 117-127. doi:10.1016/j.tate.2014.08.006 White, Elizabeth, Dickerson, Claire, and Kathryn Weston. 2015. “Developing an Appreciation of What It Means To Be a School-based Teacher Educator." European Journal of Teacher Education 38 (4): 445-459. doi:10.1080/02619768.2015.1077514 Whitty, Geoff. 2014. "Recent Developments in Teacher Training and their Consequences for the 'University Project' in Education." Oxford Review of Education 40 (4): 466-481. doi:10.1080/03054985.2014.933007

Williams, Judy. 2013. "Boundary Crossing and Working in the Third Space: Implications for a Teacher Educator's Identity and Practice." Studying Teacher Education 9 (2): 118-129. doi:10.1080/17425964.2013.808046 Winch, Christopher. 2011. "On Being a Teacher." In Becoming a Teacher: Issues in Secondary Education, edited by Justin Dillon and Meg Maguire, 12-28. Maidenhead: Open University.

Zeichner, Kenneth. 1983. "Alternative Paradigms of Teacher Education." Journal of Teacher Education 34 (3): 3-9. doi:10.1177\%2F002248718303400302 
Zeichner, Kenneth. 2010. "Rethinking the Connections Between Campus Courses and Field Experiences in College- and University-Based Teacher Education." Journal of Teacher Education 61 (1/2): 89-99. doi:10.1177\%2F0022487109347671 